\title{
KENAL KEBUN UNTUK ANAK USIA DINI
}

\author{
N. Kohdrata ${ }^{1}$, C.G.A. Semarajaya ${ }^{1}$, A.A.K. Krisnandika ${ }^{1}$, L.S. Yusiana ${ }^{1}$, A.A.A.W.S Djelantik ${ }^{2}$
}

\begin{abstract}
ABSTRAK
Pengabdian dengan judul Kenal Kebun pada Anak Usia Dini berangkat dari pemikiran untuk membuat suatu program untuk mengenalkan alam lingkungan sejak usia dini pada anak-anak usia pra sekolah. Mencari sepetak taman atau kebun di fasilitas pendidikan di wilayah perkotaan pada saat ini, khususnya Denpasar, merupakan hal yang tak mudah. Bahkan lingkungan sekolah anak-anak PAUD Permata Bunda yang menjadi sekolah untuk program pengabdian juga sangat terbatas dalam hal ketersediaan ruang hijau. Fakultas Pertanian Universitas Udayana memiliki Kebun Percobaan yang berlokasi di J1. Pulau Moyo, Denpasar, seluas 1,4 ha kiranya dapat menjadi wahana untuk pengenalan aktifitas kebun yang tepat kepada anak-anak. Metode pelaksanan adalah hands-on learning. Anak-anak usia dini akan diajak untuk mengenali beberapa tanaman kebun dan juga serangga sebagai bagian dari pengenalan langsung. Pengalaman langsung ini diharapkan makin mendekatkan mereka dengan lingkungan alami disamping menambah pengetahuan mereka akan dunia sekitar. Anak-anak diajak untuk mengenal nama-nama tanaman dengan melihat dan memegang secara langsung benda yang dimaksud.
\end{abstract}

Kata kunci : kebun, anak usia dini, hands-on learning, alam lingkungan, pengetahuan lingkungan

\begin{abstract}
Kenal Kebun in Early Childhood program idea was from the thought of creating a program to introduce the natural environment from an early age in pre-school age children. Finding a patch of gardens or gardens in educational facilities in urban areas at this time, especially Denpasar, is not easy. Even the school environment of PAUD Permata Bunda school is also very limited in terms of availability of green space. Faculty of Agriculture Udayana University has a Research Station located in Jl. Moyo Island, Denpasar, covering an area of 1.4 ha. It is a suitable site to introduce garden activities to children. The program is executed using handson learning method. Children are introduced and exposed to some garden plants and also insects. Direct experience is expected to bring them closer to the natural environment as well as increase their knowledge of the world around. Children are encourgaded to recognize the names of the plants by seeing and holding objects.
\end{abstract}

Keywords : garden, early childhood, hands-on learning, natural environment, environment knowledge

\section{PENDAHULUAN}

Lahan yang terbatas dan persaingan kebutuhan untuk beragam fasilitas yang mendukung gaya hidup perkotaan telah membuat nilai sebidang tanah menjadi sangat tinggi. Pemanfaatan lahan lebih mengutamakan peruntukan yang mendukung aktifitas yang berkaitan dengan hunian, pendidikan (ruang kelas/gedung sekolah), dan bangunan-bangunan struktur lain. Ruang hijau menjadi pelengkap yang terkadang dipaksakan keberadaannya.

\footnotetext{
${ }^{1}$ Prodi Arsitektur Pertamanan, Fakultas Pertanian Universitas Udayana, naniek_kohdrata@unud.ac.id

${ }^{2}$ Prodi Agribisnis, Fakultas Pertanian Universitas Udayana
} 
Hal ini juga terjadi di lingkungan sekolah untuk anak-anak usia dini. Salah satu sekolah yang menjadi target program pengabdian adalah PAUD Permata Bunda yang juga sangat terbatas dalam hal ketersediaan ruang hijau. Lingkungan sekolah PAUD Permata Bunda relatif tidak memiliki halaman yang representatif untuk disebut sebagai kebun atau taman. Sekolah hanya memiliki sejumlah kecil planter box yang diisi dengan tanaman hias. Minimnya lingkungan alami membuat anak makin tidak mengenal alam dan cenderung lebih akrab dengan gawai.

Kebun Percobaan Fakultas Pertanian merupakan wahana pengenalan lingkungan alami yang tepat kepada anak-anak. Kebun dapat dipakai sebagai media bagi anak-anak usia dini untuk mengenali beberapa tanaman dan juga serangga kecil di kebun secara langsung. Pengalaman langsung ini diharapkan makin mendekatkan mereka dengan lingkungan alami disamping menambah pengetahuan mereka akan dunia sekitar. Alternatif ini dipilih dengan pertimbangan bahwa penyelesaian masalah lingkungan tidak cukup hanya dengan menerbitkan undang-undang dan kebijakan-kebijakan terkait lingkungan, ataupun pembangunan-pembangunan fisik saja. Masalah yang muncul perlu didekati dari sumber masalahnya, yaitu manusia itu sendiri yang memanfaatkan alam ini. Sejak dini SDM masa depan perlu dipersiapkanuntuk peka dan peduli pada alam lingkungannya. Mentransferkan dan meneruskan pengetahuan dan kepedulian terhadap lingkungan perlu dilakukan secara terus menerus secara berkelanjutan karena generasi yang baru selalu hadir dan perlu "diisi" dengan cara-cara yang positif dalam lingkungan yang menyenangkan. Menurut Garrity (1998) metode hands-on learning efektif untuk meningkatkan pemahaman akan suatu hal, terutama pada anak.

\section{METODE PELAKSANAAN}

Pengabdian untuk mengenalkan kebun pada anak usia dini menggunakan metode hands on learning dengan teknik kombinasi manipulative learning, dan cooperative learning. Metode yang diaplikasikan mengacu pada metode hands-on learning menurut Garrity (1998). Metode ini sesuai dengan kondisi lokasi kebun percobaan yang memungkin siswa-siswa untuk aktif bergerak. Lokasi kegiatan adalah Kebun Percobaan Fakultas Pertanian Universitas Udayana (KPFP Unud) terletak di jalan Pulau Moyo, Denpasar (Gambar 1).

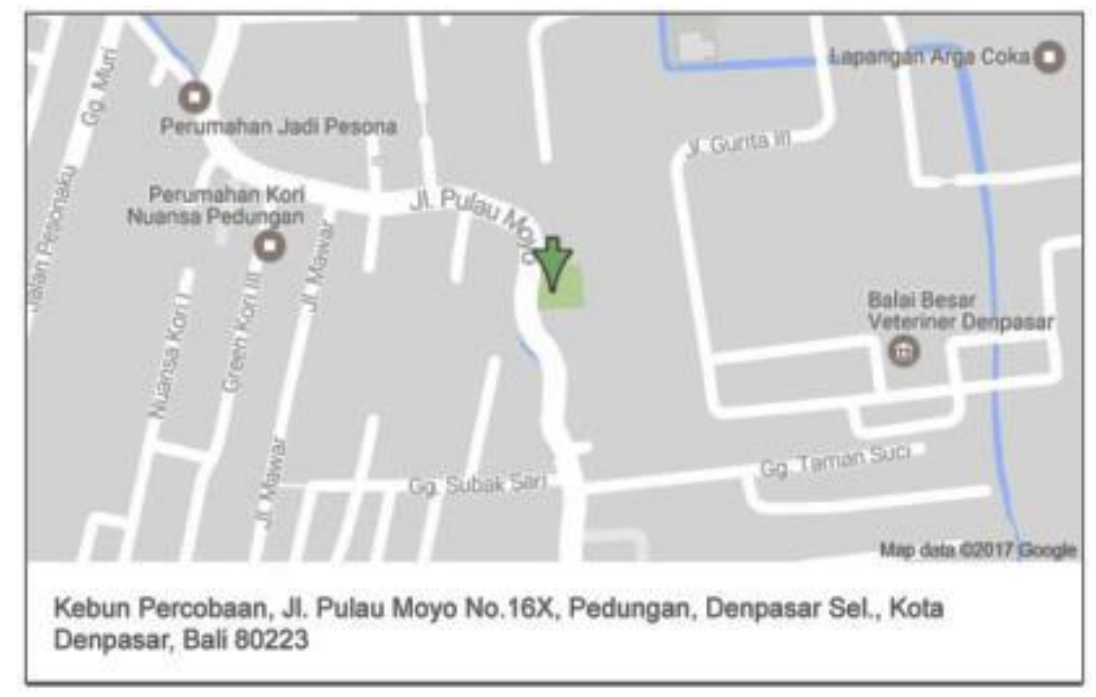

Gambar 2.1. Lokasi Kegiatan Pengabdian di KPFP Unud

Program dilaksanakan dalam dua tahapan. Tahap pertama menanam adalah mengenalkan proses menanam tanaman dan lingkungan alami kebun. Tahap kedua memanen, yaitu memberi pengalaman memanen hasil kerja 3 bulan sebelumnya dan mencicipi produk hasil tanaman. Anak-anak usia dini 
diajak mengenal nama-nama tanaman dan juga serangga yang disampaikan secara sederhana sesuai dengan usia anak.

\section{HASIL DAN PEMBAHASAN}

Program Kenal Kebun yang dilaksanakan ini menitikberatkan pada unsur edukasi meskipun unsur bermain, keseruan, dan kegembiraan tetap perlu ada dalam kegiatan. Hal ini semacam mengadakan kelas di ruang luar (outdoor class) dengan memasukkan unsur rekreasi karena anakanak akan diajak mengunjungi Kebun Percobaan Fakultas Pertanian Unud. Karena menyesuaikan dengan waktu belajar anak juga, maka aktivitas dirancang untuk dapat dilakukan dan selesai dalam waktu antara $1-1,5$ jam, termasuk diantaranya adalah waktu jeda makan untuk anak-anak. Peserta anak yang ikut dalam program ini berjumlah 34 anak, yaitu dari kelompok bermain dan TK. Program dibagi dalam dua tahapan, tahap pertama yang dilaksanakan pada akhir April 2017 diisi dengan kegiatan menanam dan pengenalan serangga. Proses menanam dilakukan dengan sistem pendampingan oleh beberapa dosen dan mahasiswa. Guludan/media tanam yang telah siap tanam disediakan sebelumnya oleh panitia. Bibit tomat, terong bulat, cabai, dan kacang edamame disiapkan sehingga memudahkan anak-anak untuk menanam pada baris-baris guludan. Terdapat empat lajur guludan yang disiapkan untuk masing-masing jenis komoditi. Guludan yang disiapkan telah ditutup dengan mulsa plastik dan disiapkan lubang-lubang untuk tanam.

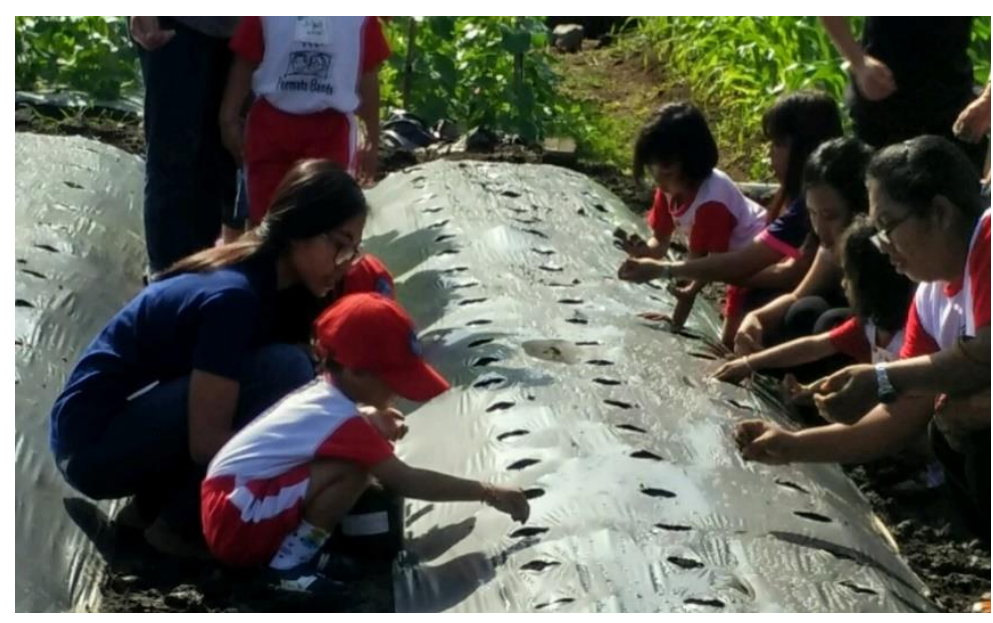

Gambar 3.1. Tahap Menanam di Kebun KPFP Unud

Tampaknya bagi anak-anak tersebut ini merupakan pengalaman pertama bertanam di kebun. Keraguraguan di wajah mereka dan langkah-langkah kecilnya saat menuju tempat untuk bertanam. Namun pada akhirnya seluruh anak antusias mengikuti kegiatan berkebun ini (Gambar 3.1). Bahkan meskipun ada yang terpeleset jatuh di lumpur, beberapa anak tersebut tidak menunjukkan reaksi menolak. Justru reaksi sebaliknya yang ditunjukkan, yaitu rasa ingin tahu dan mencoba, meskipun sebagian masih menunjukkan keragu-raguan pada awalnya. Pengalaman "bermain lumpur" saat berkebun ini dapat dirasakan berkesan untuk mereka dengan melihat dari reaksi anak-anak tersebut yang tetap ceria mengikuti seluruh rangkaian kegiatan. Setelah bertanam, mereka semua diarahkan untuk mencuci tangan dan kaki.

Proses pengenalan serangga secara khusus didukung oleh komunitas pencinta serangga Indonesia Mantis and Phasmid Forum (IMPF) yang khusus datang ke kebun untuk memperkenalkan serangga kepada adik-adik PAUD. Anak-anak tersebut juga diperkenankan untuk memegang beberapa serangga indah serangga yang menyerupai daun dan bunga yang merupakan salah satu bentuk kamuflase alami. Hampir seluruh anak menunjukkan rasa sangat ingin tahu namun geli dan 
ragu untuk memegang. Akan tetapi pada akhirnya beberapa anak mulai berani dan bahkan gembira dengan pengalaman baru menyentuh serangga-serangga tersebut (Gambar 3.2).

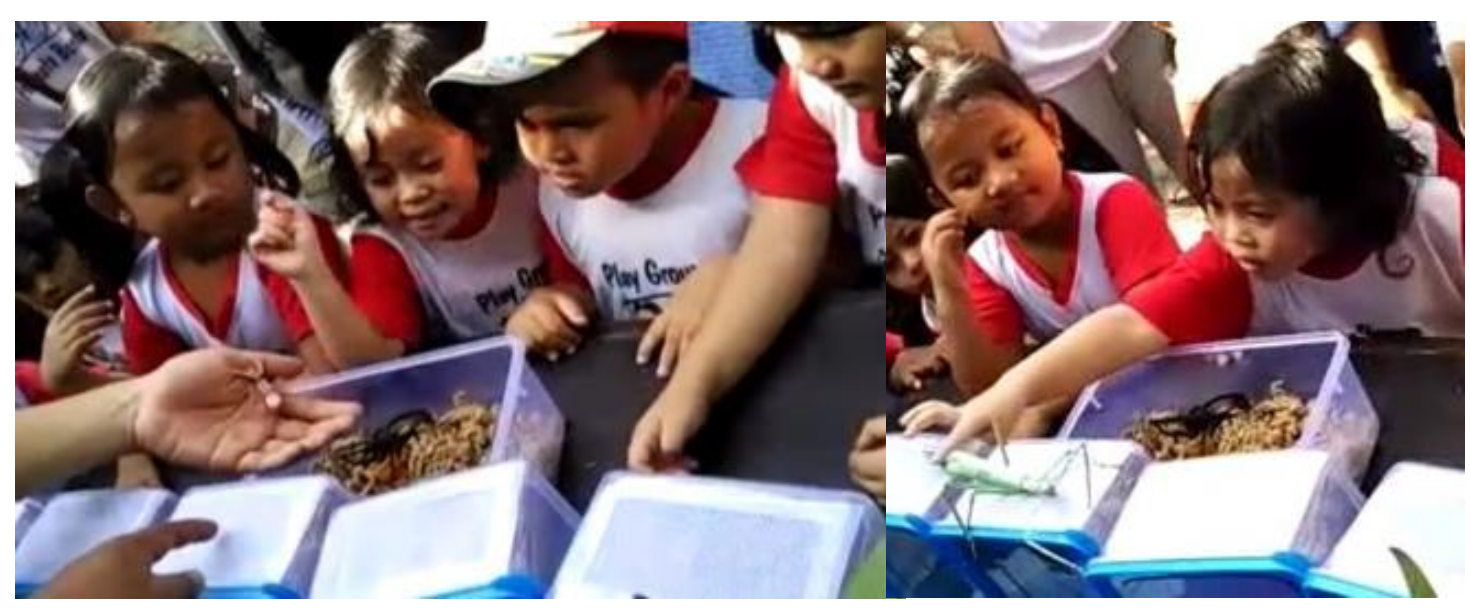

Gambar 3.2. Mengenal Serangga Indah

Aktivitas tahap menanam dibatasi dalam selang waktu 2 jam dengan pertimbangan konsentrasi dan daya tahan fisik anak usia batita yang relatif lebih cepat lelah. Disamping jugamempertimbangkan bahwa terdapat tiga jenis kegiatan, yaitu, menanam, mengenal serangga, dan mengenal lab kultur jaringan, yang ketiganya merupakan hal-hal baru baru anak-anak tersebut. Menurut Cooper, et al (2009) mengatakan bahwa pada fase pertumbuhan usia 3 - 5 tahun, seorang anak mulai masuk pada proses belajar untuk berkonsentrasi. Pada fase tersebut kisaran waktu konsentrasi anak terhadap suatu hal hanya sekitar 3 - 5 menit meskipun seorang anak tertarik pada suatu kegiatan tertentu

Tahapan kedua Kenal Kebun dikenalkan pada aktivitas memanen tanaman yang telah mereka tanam tiga bulan sebelumnya. Pemanenan awal Agustus 2017 sehingga untuk terung dan cabai agak terlewat masa puncak panen. Namun untuk tomat dan edamame relatif cukup banyak buah yang bisa dipetik. Untuk usia anak pra sekolah, tomat dan kacang edamame cukup mudah dipetik. Sementara buah terung agak sulit dan membutuhkan bantuan alat potong gunting untuk memanen. Sedangkan cabai perlu dipanen dengan hati-hati mengingat sensasi pedas cabai yang tidak begitu ramah untuk anak pra sekolah. Proses memanen ini juga melibatkan dosen dan mahasiswa sebagai pendamping anak-anak (Gambar 3.3). Saat proses pendampingan tersebut sambil diberikan pula informasi sederhana mengenai nama tanaman dan sekaligus mengingatkan mereka bahwa tanaman tersebut adalah hasil jerih payah mereka 3 bulan lalu menanam di kebun.

Setelah acara memanen selesai, anak-anak diajak untuk mengenal warna, tekstur, dan rasa dari hasil panen. Setiap anak diminta untuk kembali meraba dan mengenal tekstur dari tomat, terung, cabai, dan edamame. Kemudian anak-anak diminta untuk mencicipi buah tomat segar dari hasil yang baru dipetik. Masing-masing mendapat satu potong kecil tomat untuk dimakan. Tampaknya bagi sebagian anak yang mungkin jika di rumah mereka masing-masing enggan mencicipi sayuran segar, maka pada saat di kebun akan berbeda. Kondisi ada bersama teman-teman sebayanya membuat kegiatan mencicipi menjadi bagian dari pengalaman "petualangan" bersama bagi mereka. 


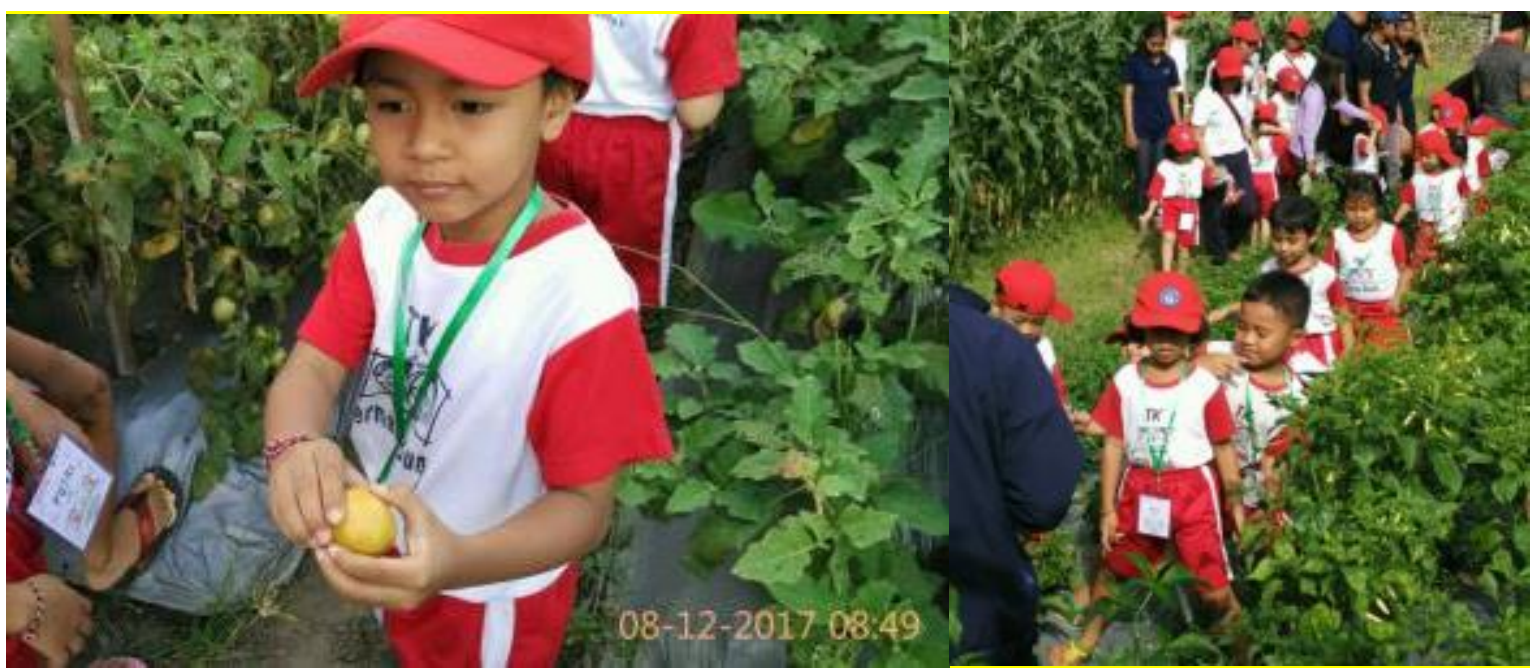

Gambar 3.3. Memanen Tomat di Kebun

Pendekatan metode hands-on learning untuk mengenalkan anak-anak usia pra sekolah antara $3-5$ tahun pada proses menanam, memanen, dan menikmati dapat dilakukan dalam setting kebun. Teknik cooperative learning tampak terjadi pada anak-anak kelas TK B (usia 5-6 tahun) terlihat adanya kerjasama sederhana, yaitu ada beberapa anak yang memetik buah tomat sementara beberapa lainnya memegang kantung plastik untuk mengumpulkan. Anak kelas TK A (4-5 tahun) umumnya relatif sibuk dengan tanaman, mulai dari hanya mengamati, memegang, dan belajar memetik. Bahkan terdapat juga anak yang sibuk dengan mengamati keramaian dan kesibukan teman-temannya saat memanen. Aspek bergerak dan berpindah tempat sebagai salah satu bentuk teknik cooperative learning pada sesi memanen merupakan hal yang paling berhasil diterapkan. Anak-anak mendapat kesempatan dan diijinkan untuk berjalan kemana saja sepanjang lajur-lajur tanaman dengan dampingan dosen, mahasiswa, dan guru PAUD. Ternyata hal ini justru mendorong mereka berinisiatif mengeksplorasi bagian lain dari kebun percobaan dengan sangat antusias. Berinisiatif yang dimaksud dalam hal ini adalah, anak-anak tersebut dengan berani, bahkan tanpa instruksi dari guru maupun dosen (orang dewasa), menjelajah ke bagian lain dari kebun yang kebetulan saat itu juga sedang terdapat tanaman yang siap panen, yaitu melon dan jagung. Antusiasme anak-anak tersebut diluar perkiraan tim panitia sehingga perlu usaha ekstra dari pendamping untuk mengejar dan mendampingi anak-anak tersebut. Reaksi anak-anak untuk mengeksplorasi tempat dimana mereka merasa aman terbukti dalam kegiatan ini. Banyaknya hal-hal yang mungkin baru bagi mereka, seperti melihat buah tomat dan melon yang masih menggantung di tanaman tampaknya sangat menarik untuk mereka dibanding saat buah tersebut sudah berada di rak-rak supermarket.

Cooper et al (2009) mengatakan bahwa anak usia 3 tahun memiliki karakter sebagai pemula yang belajar mandiri, penjelajah, dan masih mempunyai hubungan ketergantungan yang erat dengan orang dekatnya. Usia anak 4 tahun umumnya mereka mulai mengenal sekolah sehingga faktor belajar disiplin menjadi karakter utama mereka dalam mengenal aturan. Demikian pula aspek-aspek ketrampilan fisik seperti melompat, meloncat, berjalan cepat, melempar, memanjat merupakan sebagian aktivitas gerak yang mulai mereka kembangkan. Anak usia 5 tahun memiliki karakter lebih mandiri, mempunyai konsentrasi yang lebih baik sehingga mampu memperhatikan detail, serta menunjukkan pilihan pada hal-hal baru. Pada anak usia 6 tahun terjadi peningkatan yang signifikan dalam koordinasi mata dan tangan sehingga seorang anak anak lebih tangkas dan akurat dalam melakukan aktivitas sederhana. Hal ini juga diikuti dengan karakter saat menguat saat mereka menentukan pilihan. Sisi sosial mereka juga menjadi lebih baik yang ditunjukkan dengan karakter mau berbagi dan berteman. 
Kekhasan yang dimiliki masing-masing kelompok umur anak dapat menjadi kendala apabila menyatukan atau semua anak yang berbeda usia dalam satu kelompok saat beraktvitas di kebun. Potensi kendala muncul terutama dari aspek motorik, konsentrasi, dan kemampuan menerima instruksi. Sementara kondisi lingkungan kebun merupakan potensi positif untuk mengembangkan dan meningkatkan kemampuan karakter khas anak-anak dari tiap kelompok umur tersebut. Upaya mengelompokkan anak-anak yang ikut program Kenal Kebun sangat disarankan mengingat perbedaan karakter masing-masing usia. Demikian juga untuk para pendamping di kebun sebaiknya diberikan informasi mengenai karakter usia anak sehingga dapat memberi tuntun, perhatian, dan instruksi yang sesuai. Dari sisi perencanaan kegiatan juga penting untuk memperhatikan jenis-jenis aktivitas yang dapat dilakukan bersama secara sekaligus untuk semua kelompok umur dan mana saja jenis aktivitas yang dapat dilakukan kelompok umur tertentu.

Teknik manipulative learning dalam pelaksanaan program dilakukan sebagai pendukung tambahan karena secara keseluruhan program dapat dilaksanakan sesuai rencana. Anak-anak sesuai rencana dapat melihat produk tanaman hasil dari kegiatan mereka menanam tiga bulan sebelumnya. Namun untuk memberikan nilai tambah program dan dengan mempertimbangkan usia peserta Kenal Kebun, maka panitia membuatkan stiker-stiker nama untuk masing-masing anak yang diberi gambar-gambar kartun tanaman seperti buah dan sayur serta seri serangga. Stiker ini sekaligus sebagai suvenir bagi anak-anak tersebut.

\section{KESIMPULAN DAN SARAN}

Anak-anak usia dini memiliki kekhasan motorik, psikologis, dan kognitif sehingga mengajak mereka ke lingkungan baru dan mengenalkan hal baru merupakan suatu tantangan tersendiri, baik bagi anak maupun orang dewasa. Demikian pula lingkungan kebun memiliki ciri khusus sebagai suatu bentuk lingkungan binaan hijau yang dikelola manusia untuk kepentingannya. Salah satu ciri khusus kebun adalah dapat dianggap sebagai semacam mikra kosmos dari bentang alam dengan kondisi yang relatif dapat dikontrol. Hal ini memudahkan untuk membawa anak-anak kedalam pengalaman mereka di alam dalam kondisi yang terkontrol. Kendala yang muncul lebih berhubungan dengan keterbatasan motorik dan konsentrasi anak-anak usia pra sekolah yang belum sebaik anak-anak usia sekolah sehingga perlu perhatian khusus. Model program Kenal Kebun ini sangat mungkin dilakukan bagi anak-anak usia dini, terutama bagi mereka yang tinggal di lingkungan perkotaan.

\section{UCAPAN TERIMA KASIH}

Terima kasih kepada LPPM Universitas Udayana yang telah menghibahkan dana untuk skim Hibah Udayana Mengabdi tahung anggaran 2017 kepada tim pelaksana sehingga kegiatan dapat berjalan dengan lancer. Terima kasih ditujukan pula kepada PAUD Permata Bunda Denpasar yang telah memberikan kerjasama dan dukungan kemitraan yang sangat baik kepada tim.

\section{DAFTAR PUSTAKA}

Cooper, C., C. Halsey, S. Laurent, K. Sullivan. 2009. Ensiklopedia Perkembangan Anak (terjemahan). N. Lastiani (penerjemah). Penerbit Erlangga, Jakarta.

Garrity, C. 1998. Does the Use of Hands-on Learning, with Manipulatives, Improve the Test Scores of Secondary Education Geometry Student?. Tesis Program Master Saint Xavier University \& IRI/Skylight. Chicago, Illinois. 